\title{
Notes on the Useful Arts-Technological Progress as a Basis for Modern Architecture
}

\author{
Atli Magnus Seelow \\ Department of Architecture and Civil Engineering, Chalmers University of Technology, \\ 41296 Gothenburg, Sweden; atli.seelow@chalmers.se
}

Received: 28 May 2019; Accepted: 17 June 2019; Published: 19 June 2019

It is a commonplace that Modern Architecture is a product of the Industrial Revolution, as practically all representatives of the Modern Movement refer, in some way or another, to technology and regard it as the foundation of their architecture. According to established historiography, as e.g., put forward by Sigfried Giedion, it is not only inspired by avantgarde art, but also draws on 19th century engineering and the "anonymous ethos" of modern mass-society-it is architecture for the "Machine Age".

A closer look reveals that art and technology have both accompanied humankind from the beginning and share the same root-creative imagination. With the Industrial Revolution, however, technology has not only opened up unprecedented new possibilities, but has also divorced itself from art, leading to technology—i.e., handicrafts, engineering, and industry—on the one hand being considered artless, and art on other hand-i.e., poetry, music and the visual arts—useless.

In this context, Denis Diderot maintains in the Encyclopédie (1751) that the Fine Arts had praised themselves more than enough and, in the future, only the "Useful Arts" were worth considering.

With the institutionalization of architecture and engineering as modern disciplines in the late 18th and early 19th century, both grow apart not only by different traditions of education, but also by different attitudes towards technology. While architects in the 19th century are hesitant to pick up new technologies, sticking instead to "eternal values" of historicism, their "sibling rivals", engineers, harness the latest technological advancements—-designing and building engineering structures, i.e., building tasks of the industrial age, such as exhibition halls, railway stations, or bridges.

It is not until the "vertigo years" of the early 20th century, entering the proverbial "Machine Age", that art and technology seek a synthesis-architecture starts to converge with technology and industry on a broad front, ascribing, for the first time, esthetic and architectural qualities to engineering structures.

A number of avant-garde movements that emerge around World War One- - such as the Futurists in Italy, the Constructivists in Russia, De Stijl in the Netherlands, Deutscher Werkbund or, later, Neues Bauen and the Bauhaus in the Weimar Republic-adopt modern technology with a predominantly artistic enthusiasm, establishing an esthetic promise of technological progress.

The theme of this issue, i.e., to investigate the significance of this technological progress for the emergence and development of Modern Architecture, entails a number of topics on different levels, as shown by the individual articles.

First, the topic builds on the recent material turn in architectural history and on findings in neighboring scientific fields, such as construction history and the cultural history of technology.

Many exemplary designs in architectural history convey an esthetic promise of progress and are designed according to functional, rational, or utilitarian principles-with a new tectonic expression and a machine esthetic with attributes such as transparent facades, a modular order, and without ornaments. So investigating how new materials (iron, glass, concrete), new concepts (standardization, modularization, mass production), constructions (curtain wall glass facades, flat roofs), and the 
mechanization of buildings evolve, parallel to the modernization of architecture, shows us how technological progress, on a material level, changes architectural thinking and the built form.

Second, this issue examines how architects deal with technological progress: Are they active protagonists or only recipients in adapting innovations to achieve a new architectural expression? Does the desire for a new architecture precede or promote the development of corresponding technological innovations? And do their buildings—in reality and on a material level-live up to the esthetic promise of progress?

Third, this leads to a re-evaluation of the relationship between architect and engineer, i.e., it asks if engineers, as protagonists of the Industrial Revolution, also anticipate architectural progress or vice versa.

Fourth, the research compiled here challenges the established historiography, which seems to be long overdue in a contemporary globalized world increasingly defined by technology. It builds on a concept of progress that goes beyond the idea of a continuous progression purposefully leading to the present, but on the contrary, a concept that, as Walter Benjamin points out, is based on a historicization of modernism and includes both the destruction of the past and the construction of the future.

The interaction between art and technology helps to trace the mechanisms of technological vs. architectural progress and to illuminate their role in Modern Architecture, to complement its historiography with the hitherto largely missing aspect of technology in order to depict Architecture as a "Useful Art".

Funding: This research received no external funding.

Conflicts of Interest: The author declares no conflict of interest.

(C) 2019 by the author. Licensee MDPI, Basel, Switzerland. This article is an open access article distributed under the terms and conditions of the Creative Commons Attribution (CC BY) license (http://creativecommons.org/licenses/by/4.0/). 